\title{
VALIDATION OF AN INSTRUMENT FOR INVESTIGATING KNOWLEDGE ON THE INITIAL ASSISTANCE TO BURNS VICTIMS ${ }^{1}$
}

\author{
Marli Aparecida Joaquim Balan², William Campo Meschial², Rosangela Geritana Santana , Simone Mancini \\ Liduário Suzuki ${ }^{5}$ Magda Lúcia Félix de Oliveira ${ }^{6}$
}

\begin{abstract}
${ }^{1}$ Article extracted from the dissertation "Construction of a questionnaire for analyzing knowledge on the initial assistance to burns victims" presented to the Postgraduate program in Nursing at the State University of Maringá (UEM) in 2008.

${ }^{2}$ MSC in Nursing. R.N at the Regional University Hospital of Maringá. Maringá, Paraná, Brazil. Email: marlibalan@hotmail.com

${ }^{3}$ MSC student on the Postgraduate program in Nursing at UEM, Maringá, Paraná, Brazil. Email: williameschial@yahoo.com.br

${ }^{4}$ Ph.D in Statistics. Professor of the Department of Statistics, UEM. Maringá, Paraná, Brazil. Email: rgsantana@uem.br

${ }^{5}$ R.N. at the Regional University Hospital of Maringá. Maringá, Paraná, Brazil. Email: mancinisuzuki@bol.com.br

${ }^{6}$ Ph.D in Public Health. Adjunct professor IV of the Department of Nursing, UEM. Maringá, Paraná, Brazil. Email: mlfoliveira@ uem.br
\end{abstract}

\begin{abstract}
This study featured a methodological quantitative approach and its objective was to validate an instrument on the initial assistance given to burns victims, on medical and nursing knowledge, using the theoretical stage of Pasquali's model. The data were collected in June - August 2008, in two parts: analysis of face validity and content validity by 18 judges; and analysis of internal consistency, undertaken through Item Response Theory, by 42 doctors and nurses from a teaching hospital in the North-West region of the Brazilian state of Paraná. Following the judges' analysis, 35 questions regarding general, medical and nursing knowledge showed agreement above $80 \%$ for the concepts. Through the internal consistency analysis applied to the general knowledge questions, three were discarded due to not being correlated with the construct. The remaining seven questions $(70 \%)$ presented low discrimination of the respondents, varying levels of difficulty, and similar probabilities of correct random guesses. The final instrument contains 32 questions and is available for use.
\end{abstract}

KEYWORDS: Validation studies. Burns. Emergency medical services. Emergency nursing. Nursing.

\section{VALIDAÇÃO DE UM INSTRUMENTO DE INVESTIGAÇÃO DE CONHECIMENTO SOBRE O ATENDIMENTO INICIAL AO QUEIMADO}

\begin{abstract}
RESUMO: Pesquisa de desenvolvimento metodológico de abordagem quantitativa, cujo objetivo foi validar um instrumento sobre atendimento inicial ao queimado voltado para o conhecimento de médicos e enfermeiros, utilizando a etapa teórica de Pasquali. Os dados foram coletados em junho-agosto de 2008, em dois momentos: análise aparente e de conteúdo por 18 juízes; e análise da consistência interna, através da Teoria de Resposta ao Item, por 42 profissionais médicos e enfermeiros de um hospital-ensino da Região Noroeste do Paraná. Após análise dos juízes, 35 questões sobre conhecimento geral, médico e enfermagem apresentaram concordância nos conceitos, superior a $80 \%$. Através da análise da consistência interna aplicada às questões de conhecimento geral, foram descartadas três questões, por não estarem correlacionadas com o construto. As demais sete (70\%) apresentaram baixa discriminação dos respondentes, graus de dificuldade variados e probabilidades similares de acerto ao acaso. O instrumento final contém 32 questões e encontra-se disponível para utilização.
\end{abstract}

PALAVRAS CHAVE: Estudos de validação. Queimaduras. Serviços médicos de emergência. Enfermagem em emergência. Enfermagem.

\section{VALIDACIÓN DE UN INSTRUMENTO DE INVESTIGACIÓN DE CONOCIMIENTO SOBRE LA ATENCIÓN INICIAL AL QUEMADO}

\begin{abstract}
RESUMEN: Investigación de desarrollo metodológico de abordaje cuantitativo, cuyo objetivo fue validar un instrumento sobre atención inicial al quemado dirigido al conocimiento de médicos y enfermeros, utilizando la etapa teórica de Pasquali. Los datos fueron recolectados en junio-agosto de 2008, en dos momentos: análisis aparente y de contenido por 18 jueces; y análisis de la consistencia interna, por la Teoría de Respuesta al Ítem, por 42 profesionales médicos y enfermeros de un hospital escuela. Después del análisis, 35 cuestiones sobre conocimiento general, médico y enfermería presentaron concordancia por encima de $80 \%$ en los conceptos. A través del análisis de la consistencia interna, aplicada a las cuestiones de conocimiento general, fueron desechadas tres por no estar correlacionadas al constructo. Las otras siete (70\%) presentaron baja discriminación de los participantes, grado de dificultad variado y probabilidad de acierto al acaso similares. El instrumento final contiene 32 cuestiones y se encuentra disponible para utilización.
\end{abstract}

PALABRAS CLAVE: Estudios de validación. Quemaduras. Servicios médicos de emergencia. Enfermería de urgencia. Enfermería.

Text Context Nursing, Florianópolis, 2014 Abr-Jun; 23(2): 373-81. 


\section{INTRODUCTION}

Burns and their consequences are considered real public health problems, as their victims represent a heavy social and economic burden during the long period of hospitalization and recovery process. They are among the most complex and serious traumas, given that important consequences can occur - such as scarring and other physical sequelae - which cause disabilities, psychological suffering and disfiguration, resulting in a long recovery period. ${ }^{1}$

Burns and fires are responsible for more than 300,000 deaths per year worldwide; in addition to this, a large proportion of the non-fatal accidents tend to be disabling, mainly in low- and middleincome countries, where there are no programs for prevention and the quality of care in the acute phase is poor. ${ }^{2}$

Burns are classified as traumatic wounds, resulting from the excessive action of heat, result in protein denaturation and lead to the partial or total destruction of the exposed tissues, affecting from the epidermis to deeper tissues. A thermal injury can be manifested as a blister or in more serious forms, which cause systemic alterations..$^{3-4}$

In Brazil, according to the Brazilian Burn Society, it is estimated that one million cases of burns occur each year, of which 200,000 are attended in Emergency Room, and 40,000 require inpatient treatment. In Brazil, the rates of mortality from burns are high, being inferior only to those from transport accidents and homicides. ${ }^{5}$

The initial assistance to the burns victim in the acute phase is that undertaken in the hospital environment from the moment in which the burns victim enters the stabilization room until 48 to 72 hours after the occurrence of the burn. In this phase, the principal objective is to interrupt the burn process and treat the conditions which place the victim's life at risk, this being a period in which appropriate treatment is considered essential for the recovery of the person with the burn. ${ }^{6}$

The initial approach to the burns victim is undertaken in emergency units in the midst of the tension which pervades the professionals in these services on a daily basis. The team responsible for this assistance must possess knowledge of the area based in already-established scientific principles, in addition to being trained and articulated so as to reduce these patients' morbidity and mortality. ${ }^{4}$

In one epidemiological study undertaken with burns victims, in the Emergency Room of a teaching hospital, attention was called to the fact that the evaluation of the characteristics of the burns was made based on their depth and location, without reference to the measurement of the Body Surface Area Burned (BSAB), a data of extreme importance for defining the appropriate procedures and referrals. ${ }^{7}$ Another study on various aspects of the assistance to the burns victim emphasizes that the lack of records of the assistance provided weakens the studies undertaken in Brazil in this area. ${ }^{8}$

These occurrences motivated questions regarding the knowledge, on the part of the health team, of significant aspects of the treatment provided to burns victims. This is an important point to be revealed, as the first assistance is not given in the specialized units and has consequences for these patients' survival.

In Holland, evaluation of doctors' and nurses' knowledge regarding the assistance given to burns victims evidenced that these professionals lack theoretical-practical knowledge regarding this issue. It was also ascertained that those professionals who had undertaken the training in Emergency Management of Serious Burns had better theoretical knowledge of the treatment protocols and benchmarks than the professionals who had not. ${ }^{9}$

In studies undertaken in Turkey ${ }^{10}$ and Vietnam ${ }^{11}$ for assessing the health team's knowledge regarding assistance to burns victims, gaps were evidenced in the theoretical knowledge and the technical-assistential practices of the professionals investigated. These studies' authors suggested the undertaking of refresher courses and continuous education in this area.

In Brazil, there are no publications focusing specifically on verifying the knowledge of the professionals who provide the initial assistance for burns victims, and there is no instrument or scale for evaluating the knowledge, validated on a national scale. In this context, the creation of a measurement instrument in this area could bring contributions for the bodies managing and training professionals from the health area. For this, it is necessary to assess the level of professional knowledge necessary for this assistance, and to identify any gaps in the training and updating of the professionals.

Nevertheless, the task of creating a measurement instrument is a major challenge and must be undertaken with methodological rigor, through well-defined and precise steps and procedures. ${ }^{12}$ The process of validating an instrument, in its turn, 
can be understood as a methodological procedure evaluating the instrument's capacity to accurately measure that which it intends to assess, that is, the phenomena under study. ${ }^{13-14}$

In this regard, the present study aims to validate an instrument on the initial assistance provided to burns victims, focusing on the knowledge of the doctors and nurses.

\section{METHOD}

The study consisted of a methodological study with a quantitative approach focusing on the development, evaluation and improvement of instruments and of methodological strategies. ${ }^{15}$ The research project was submitted to the Committee for Ethics in Research Involving Human Beings of the State University of Maringá (COPEP/UEM), being approved under Decision N. 036/2008. Authorization to undertake the study was requested and obtained from the teaching hospital where the pre-test was undertaken.

As a methodological framework for constructing the instrument, Pasquali's Theory of the Elaboration of Psychological Scales was used, which is made up of 12 steps which include specific tasks and methods, grouped into three domains: theoretical pole, empirical or experimental pole and the analytical or statistical pole..$^{12,16}$

The theoretical pole refers to the theoretical base of the construct for which one wishes to elaborate a measurement instrument; the empirical pole is made up of the stages and techniques for applying the pilot instrument, as well as of the collection of information allowing the evaluation of the instrument's psychometric properties; and, finally, the analytical pole encompasses the statistical analysis of the data, with the aim of validating the instrument. ${ }^{12,16}$

This theory was chosen because it provides clear steps for elaborating a measuring instrument, and is geared towards psychological evaluation. Adjustments were made in the terminology, such as the substitution of the construct's constitutive and operational definition with the definition of the domains of the theme "Burns".

\section{Theoretical pole for the development and validation of the instrument}

The theoretical basis for construction of the questions was made based on a broad bibliographic review of Brazilian and international publications, and on well-established references in the areas of nursing and medicine, factors which underpin the definition supporting the items for evaluating knowledge.

Sixty multiple-choice questions were elaborated, in which the issue of initial assistance to the burns victim was dimensioned in the areas of general knowledge (twenty questions), nursing knowledge (twenty questions) and medical knowledge (twenty questions) regarding burns. In the editing process, it was sought to be attent to aspects such as objectivity, simplicity, relevance, accuracy, credibility, clarity, and suitability of the language to the target population, so as to correctly evaluate the objective proposed. Each question was followed by the options "I agree", "I disagree", and "I don't know".

The instrument was analyzed regarding the content validity and face validity, through the judgement of a team of eight experts and ten health professionals, respectively. The experts selected were four doctors, two masters and two specialists, with knowledge, skill and clinical experience in the area of burns.

\section{Empirical or experimental pole for validation of the instrument}

In order to proceed to a later statistical analysis of the instrument's internal consistency or homogeneity, that is, to check if all the items evaluated aspects of the same concept, rather than different concepts, and thus bestow reliability on the measurement instrument, a pre-test was carried out with the pilot instrument. The population was made up of nurses and doctors from the pediatric and surgical specialities who worked in the Emergency Care Unit of a teaching hospital in the North West region of Paraná, where they provided initial assistance to patients with burns.

Staff who were on holiday, on special leave or on sick leave at the time of data collection were excluded from the study. No sample calculation was undertaken, as all the professionals described received the questionnaire beforehand. Finally, 21 nurses and 21 doctors agreed to participate in the research and responded to the questionnaire.

The professionals were approached during 10 days, in October 2008. After the participants had signed the Terms of Free and Informed Consent, the researcher and the previously-trained volunteer monitors proceeded to data collection, which consisted of handing over the instrument in sealed 
envelopes, so as to maintain anonymity. The instruments were later returned to the investigators.

In the questionnaire administered there were questions referent to the respondents' sociodemographic characterization, and previously validated questions about the Instrument for the investigation of knowledge regarding the initial assistance to burns victims.

\section{Analytical or statistical pole}

In order to estimate the instrument's internal consistency, statistical analysis of the data collected in the pre-test mode was undertaken, using the Item Response Theory (IRT), and was processed using Software Bilog for Windows ${ }^{\circledR}$.

The IRT is a powerful tool for evaluating instruments, as the probability of correct responses to the instrument's questions depends on the respondent's skill, which varies according to her latent trait and the items' parameters. ${ }^{12}$ For this electronic processing, the responses of the 43 professionals, obtained through the administration of the pre-test, were coded and inserted in electronic spreadsheets. The analysis of the instrument's internal consistency was undertaken by the correlation between the items and by the estimation of the same items' parameters.

In the first phase of the analysis of the instrument's items, the evaluation of the biserial correlation coefficient was made. This measures the correlation of the results of an item with the raw total score of the test, as well as its ability to discriminate items in relation to the result of the test. In this analysis, the Pearson's Correlation Coefficient and a mathematical expression which considers the parameters of distribution which it is possible to obtain were associated.

In the second phase, the items' calibration was undertaken for the calculation of the parameters: $a$ - discrimination or slope of the item; $b$ - difficulty (measured in the same latent trait metric); and c - probability of getting a correct answer for an individual with low proficiency. The model which allowed the most satisfactory analysis was the logistic model with three parameters, through the IRT. The analysis of the three parameters is presented in the form of tables with the rates of discrimination, difficulty and probability of getting a correct answer by random guessing and the standard-error obtained.

\section{RESULTS}

In the instrument for investigating knowledge on the initial assistance to burns victims, which initially had 60 questions and three areas, these were segmented into domains. For the general knowledge on burns, the following domains were selected and conceptualized: the concept of burns, classification of the severity of the burn, calculation of the body surface area burned in the adult patient and in the child, physiopathology of burns, basic examination, data collection, immediate care, initial care, inhalation injuries; local care; positioning of the burns victim, and vital signs. For the area of nursing, the domains were as follows: the initial nursing care, intensive care; vital signs, care of the wound and prevention of infection. For the medical area, the following domains were selected and conceptualized: volemic replacement; burns triage; analgesia; antibiotic therapy; antitetanus prophylaxis, and complementary tests; specific burns, vital signs and nutritional support. The domains were conceptualized according to a reference bibliography from each area and formed the basis for the creation of each one of the sixty multiple-choice questions, subdivided equally between the three areas of knowledge.

For the content validation, eight judges analyzed the 60 questions, supported by the "Guide for analysis of the questionnaire's psychometric properties", ${ }^{12}$ made up of eight items. The judges had to verify, regarding each question, the aspects of objectivity, simplicity, relevance, accuracy, credibility, clarity, suitability of the language and degree of difficulty.

The criteria of $80 \%$ agreement between the judges was adopted for analysis of the questions. All the questions which had agreement below $80 \%$ or a score below three for any of the items of objectivity, simplicity, relevance, accuracy, credibility, clarity and suitability of the language were discarded from the instrument, due to being considered reasonable, poor or very poor, in accordance with Pasquali's recommendation. ${ }^{12}$ As there was no agreement between the evaluators regarding the degree of the item's difficulty, and as the difficulty of the question was linked to the respondent's attitude, the researchers chose to analyze this aspect of the questions later, using statistical analysis.

Thirty-five questions had agreement above $80 \%$, that is, they were evaluated as good or very good regarding the above-mentioned aspects, 
demonstrating that they had content which covered relevant aspects of the knowledge regarding initial assistance to the burns victim. Ten of the general knowledge questions were discarded because they did not achieve content validity; three questions from the nursing area were also eliminated, as were 12 questions from the medical area.

Thus, the instrument for verifying nursing knowledge remained with ten general knowledge questions, and 17 specific nursing questions, while the instrument for verifying medical knowledge remained with the same 10 general knowledge questions, identical to those in the nursing instrument, with the addition of eight items specific to the medical area.

The later stage was that of verifying the instrument's face validity. It is recommended that in this phase, the questions should be analyzed by a more sophisticated sample of subjects with greater skill, and also by the lower strata, with lesser ability, of the target population. This phase aims to ascertain whether the population at which the instrument is aimed will understand all the items selected. ${ }^{12}$

Two experienced doctors and two experienced nurses, with more than two years' experience of working in the area, and three recentlyqualified nurses and three recently qualified doctors, were requested to read the 35 questions and to discuss points which were not clear in the questions. Their suggestions regarding semantic changes, the improvement of the editing and of the revision of the text in question 5, 7, and 10 in the area of general knowledge of burns were accepted, which allowed a better theoretical connection with the domains selected, thus arriving at the pilot instrument's face validity.

In order to validate the instrument statistically, its internal consistency was analyzed by a pre-test with the instrument, in a pilot sample made up of 21 nurses $(49.0 \%)$ and 22 medical doctors $(51.0 \%)$. In relation to age range, the majority of these professionals was made up of young adults aged between 20 and 39 years old $(55.0 \%)$, with a slight female majority (51.0\%). Regarding academic training, the majority had the title of specialist $(58.2 \%), 29.7 \%$ had M.As, $11.6 \%$ had Ph.Ds, and $2.3 \%$ had only undergraduate degree.

Table 1 presents the statistics resulting from the analyses of the 10 items of the general knowledge test regarding the initial assistance to burns victims. The Pearson coefficient varied between -0.952 and 0.604 in the ten items evaluated. The items which presented a Pearson coefficient equal to zero (items 1, 2 and 9) were excluded, as they did not contribute to the analysis of the construct under study. The biserial correlation coefficient, which measures the correlation between the items, was also obtained, which evidenced a negative correlation for item 9 .

Table 1 - Biserial correlation of the 10 items for the general knowledge test regarding initial assistance for the burns victim. Maringá, State of Paraná (PR), 2008

\begin{tabular}{lccc}
\hline Domains & Question & Pearson C. & Biserial C. P. \\
\hline First attendance: basic examination & 1 & 0.322 & 0.551 \\
First attendance: initial care & 2 & 0.000 & 0.000 \\
First attendance: initial care & 3 & 0.000 & 0.000 \\
Calculation of BSAB in the adult patient and the child & 4 & 0.408 & 0.518 \\
First attendance: local care & 5 & 0.186 & 0.266 \\
First attendance: local care & 6 & 0.123 & 0.156 \\
First attendance: local care & 7 & 0.604 & 1.033 \\
Positioning of the burns victim & 8 & 0.421 & 0.528 \\
Vital signs & 9 & 0.557 & -0.952 \\
Physiopathology of the Burns & 10 & 0.147 & 0.211 \\
\hline
\end{tabular}

Processed by: Bilog-Mg Item Maintenance Program: Logistic Item Response Model.

Table 2, below, presents the corrected biserial correlation after exclusion of the non-correlated items and item 9, which was not in the same direc- tion as the others, which evidences indices closer to 1 and reflects the item's capacity for identifying the result of the test. 
Table 2 - Biserial correlation of the seven items for the general knowledge test regarding initial assistance to the burns victim. Maringá (PR), 2008

\begin{tabular}{lccc}
\hline Domains & Question & Pearson C. & Biserial C. P. \\
\hline First attendance: basic examination & 1 & 0.570 & 0.832 \\
Calculation of the BSAB in the adult patient and in the child & 4 & 0.528 & 0.663 \\
First attendance: local care & 5 & 0.331 & 0.483 \\
First attendance: local care & 6 & 0.300 & 0.384 \\
First attendance: local care & 7 & 0.729 & 1.064 \\
Positioning of the burns victim & 8 & 0.516 & 0.649 \\
Physiopathology of the burns & 10 & 0.414 & 0.555 \\
\hline
\end{tabular}

Processed by: Bilog-Mg Item Maintenance Program: Logistic Item Response Model.

Table 3 presents the calculation of the items parameters. For these items, calibration was undertaken with the following parameters: a discrimination or slope of the item, $b$ - difficulty (measured in the same latent trait metric) and c - probability of a correct answer for an individual with low proficiency.

It may be observed that all the "a"s are practically equal, varying from 0.926 to 1.052 . In relation to difficulty, one can say that the items vary, as they present parameters varying from -1.3 to 1.2 . The probability of getting a correct answer by chance is approximately equal for all the items. In this way, other items were not excluded and the final instrument remained with 32 questions. This is available online in the Bank of Dissertations and Theses of the Postgraduate Program in Nursing of the State University of Maringá (PSE/UEM), and may be accessed at: www.pse.uem.br.

Table 3 - Calculation of the parameters of the seven items of the instrument for analyzing the area of general knowledge. Maringá (PR), 2008

\begin{tabular}{|c|c|c|c|c|}
\hline Domains & Item & Discrimination (a) & Difficulty (b) & Correct guessed answer (c) \\
\hline \multirow[t]{2}{*}{ First attendance: basic examination } & 1 & 1.048 & -1.263 & 0.724 \\
\hline & & $0.507^{*}$ & $0.756^{*}$ & $0.350^{*}$ \\
\hline \multirow{2}{*}{$\begin{array}{l}\text { Calculation of the BSAB in the adult } \\
\text { patient and in the child }\end{array}$} & 4 & 0.934 & -0.494 & 0.682 \\
\hline & & $0.430^{*}$ & $0.725^{*}$ & $0.314^{*}$ \\
\hline \multirow[t]{2}{*}{ First attendance: local care } & 5 & 1.051 & 1.214 & 0.725 \\
\hline & & $0.517^{*}$ & $0.880^{*}$ & $0.356^{*}$ \\
\hline \multirow[t]{2}{*}{ First attendance: local care } & 6 & 0.949 & 0.311 & 0.688 \\
\hline & & $0.446^{*}$ & $0.575^{*}$ & $0.324^{*}$ \\
\hline \multirow[t]{2}{*}{ First attendance: local care } & 7 & 1.052 & -0.730 & 0.725 \\
\hline & & $0.520^{*}$ & $1.011^{*}$ & $0.358^{*}$ \\
\hline \multirow[t]{2}{*}{ Positioning of the burns victim } & 8 & 1.035 & -0.230 & 0.719 \\
\hline & & $0.506^{*}$ & $0.651^{*}$ & $0.352^{*}$ \\
\hline \multirow[t]{2}{*}{ Physiopathology of the burns } & 10 & 0.926 & -1.371 & 0.679 \\
\hline & & $0.426^{*}$ & $0.882^{*}$ & $0.313^{*}$ \\
\hline
\end{tabular}

* Standard Error Largest Change $=1.208458$.

\section{DISCUSSION}

An adequate measurement instrument results from methodological exactitude, welldefined stages and accurate methods. ${ }^{12,16}$ Due to this, the Theory of the Elaboration of Psychological Scales was sought for guiding the steps of the construction, giving rigor and methodological seriousness.
A recently-created instrument, whose aim is to analyze qualitative data - such as knowledge, for example - must have its validity measured, as this brings quality and reliability to its use. In validating the content of the measurement instrument, the choice of judges must be careful, as it falls to them to judge to which degree each characteristic of the construct is being covered by the items of 
the proposed instrument, which influences the reliability of the results obtained. ${ }^{12,16}$

The judges' analysis verifies the suitability of the behavioral aspect of the latent attributes. It is made by experts in the area of the construct, whose task is to judge whether the items refer or not to the trait in question, so as to be able to validate the hypothesis that they are able to adequately represent the construct. ${ }^{12}$

An agreement of at least $80 \%$ or of six judges can serve as a decision criterion regarding the relevance of the item to the trait to which, theoretically, it refers. ${ }^{12}$ The 35 questions which presented content validity achieved, according to the judges' evaluation, satisfactory levels of objectivity, simplicity, relevance, accuracy, credibility, clarity and suitability of the language, demonstrating that they have content which covers relevant aspects of the knowledge regarding assistance of the burns victim. This allows the assertion that the items included in the pilot instrument are those which have real theoretical validity, and not just the appearance of validity, as they satisfied the recommendations and the content analysis proposed in the Theory for the Elaboration of Psychological Scales. ${ }^{12,16}$

Items submitted to a theoretical reflection have face validity. In this phase the questions must be evaluated by a more sophisticated sample of subjects from the target population, some with greater and some with lesser ability. ${ }^{12,16}$ This stage is crucial in the development of the construct, as the content must transmit the information clearly, so that this may be understood by the target public and that erroneous interpretations may be discarded. ${ }^{17}$ The judges who made this analysis in the present study met these requirements and their suggestions for adjustments were respected, giving greater intelligibility to the questions.

For practical validation of the instrument, the analytical pole was undertaken for calculating the internal consistency. ${ }^{12}$ To this end, a pre-test of the instrument was undertaken in an emergency care unit.

Emergency units provide high complexity care to individuals at imminent risk of death. It falls to the doctor to make the diagnosis and lead the treatment, and to the nurse, to provide the care and manage the unit. Thus, the pilot-sample was shown to be adequate, as it covers the main professionals who assist the burns patient in the initial phase. In international studies, these were also the professionals questioned, who provide the initial assistance to burns victims. ${ }^{9,11}$
To have internal consistency, the instrument must homogeneously identify, to a greater or lesser extent, the health professionals' knowledge regarding the initial assistance to the burns victim. ${ }^{12}$

The Pearson coefficient varied from -0.952 to 0.604 in the 10 items evaluated. This allows one to assert that each item's contribution is sufficiently effective to justify the effort of using it. ${ }^{18}$ The biserial correlation coefficient measures the correlation between the items. The closer to 1 or -1 , the more the item is correlated with the others. The coefficient must not be negative, as this is in an opposite direction from the other items. If this index is close to zero, or is negative, it indicates that the question could not distinguish the professionals who have knowledge from those who do not, and, for this reason, do not have the necessary quality.

In tests made up of binary or dichotomous items, which accept two possible results, the biserial correlation and the biserial point correlation were evaluated, which are measurements of the item's discriminatory ability in relation to the result of the test. The biserial point correlation or Pearson's correlation is an expression which evaluates the parameters of the distribution which can be obtained. ${ }^{18}$ Thus, the seven items which remained demonstrated adequate rates of discrimination of the professionals in relation to the extent of their knowledge, and of each item in relation to the final result of the test.

The difference in using the IRT lies in its possibility to evaluate each item in isolation, creating parameters for evaluating the items. The parameter " $a$ " is the discrimination index which indicates how much subjects with different knowledge differ in relation to the probability of getting a correct answer for an item: it is problematic if " $a$ " is below $0.30,{ }^{18}$ which did not occur in this case, showing that this instrument does not discriminate between the respondents, which is a quality, as there was no intent to classify the respondents.

Parameter " $b$ " refers to the item's difficulty index. If " $b$ " is equal to -3 , the item is extremely easy; if zero, it is of medium difficulty; if 3 , it is extremely difficult. In relation to difficulty, the items vary, and do not reach a level of extreme difficulty to answer; parameter " $\mathrm{c}$ ", on the other hand, is the probability of getting a correct answer by chance. ${ }^{18}$ In this instrument, the probability of getting a correct answer by chance is approximately equal for all the respondents.

In the light of these considerations and considering the items' characteristics, the instrument 
analyzing general knowledge regarding burns achieved a good level of internal consistency, that is to say, the questions evaluated, homogeneously, to a greater or lesser extent, the general knowledge that health professionals have regarding the initial assistance to burns victims. It can be said that the instrument is calibrated, but it is important to emphasize that the calculations have high standarderrors, as the sample size was not sufficient to satisfactorily calculate the model's parameters. Authors who work with the IRT recommend that in order to calculate accurate parameters, the sample must be made up of a minimum of 200 individuals. ${ }^{12,16,18}$

It should be emphasized, however, that evaluation of the validity of any measurement instrument must be a continuous and ongoing process, so as to allow the early detection of any needs for adaptation or reformulation, taking into account the different contexts which use it. ${ }^{19}$

It was not possible to undertake statistical analysis of the questions concerning the specific nursing or medical knowledge, as the sample of respondents for each area of knowledge was small; however, the face validation and content validation were undertaken, allowing the instrument to be reproduced in later studies.

\section{CONCLUSIONS}

The instrument developed for analysis of health professionals' knowledge regarding the initial assistance to burns victims contains questions evaluating general knowledge regarding burns, and specific questions for nurses and doctors, and is a new instrument in Brazil. It has content validity and face validity, attested by a team of experts, and has been proven to have the theoretical characteristics necessary for evaluation of the issue. The general knowledge questions have internal consistency by the IRT. The methodology selected was followed comprehensively for construction and validation of the instrument.

The adaptation of the Theory of the Elaboration of Psychological Scales for an innovative proposal for the creation of an instrument for evaluating knowledge, with adjustments of some points of the process, as well as of the instrument itself which was constructed and validated for theoretical evaluation of the knowledge regarding the initial assistance to the burns victim, was a relevant contribution to the study.

It is recommended that in future studies, the sample should be increased to change the parameters of the questions of the three areas of knowledge, as in this study the size of the sample limited the study. As this is an instrument for ascertaining knowledge, it must be periodically reviewed, so as to remain up-to-date, thus viabilizing its applicability.

Further studies administering this instrument are considered essential, as there is a real need to identify health professionals' knowledge on this issue, as this would support educational interventions, or even curricular alterations in the professional training, with a view to better preparation in this area.

\section{REFERENCES}

1. Dutra AS, Penna LHG, Vargens OMC, Serra MCV. Caracterização de mulheres hospitalizadas por queimaduras. Rev Enferm UERJ. 2011Jan-Mar; 19(1):34-9.

2. Peck MD. Epidemiology of burns throughout the world. Part I: distribution and risk factors. Burns. 2011 Nov; 37(7):1087-100.

3. Balan MAJ. Lesão por queimadura. In: Balan MAJ. Guia terapêutico para tratamento de feridas. São Caetano do Sul (SP): Difusão Editora; 2006.

4. Lima Junior EM, Novaes FN, Piccolo NS, Serra MCVF. Tratado de queimaduras no paciente agudo. São Paulo (SP): Editora Atheneu; 2009.

5. Oliveira TS, Moreira KFA, Gonçalves TA. Assistência de enfermagem com pacientes queimados. Rev Bras Queimaduras. 2012 Jan-Mar; 11(1):31-37.

6. Associação Médica Brasileira. Projeto diretrizes: queimaduras. São Paulo (SP): AMB, 2002.

7. Balan MAJ, Oliveira MLF, Trassi G. Características das vítimas de queimaduras atendidas em unidade de emergência de um hospital escola do Noroeste do Paraná. Cienc Cuid Saude. 2009 Abr-Jun; 8(2):169-75.

8. Montes SF, Barbosa MH, Sousa Neto AL. Aspectos clínicos e epidemiológicos de pacientes queimados internados em um hospital de ensino. Rev Esc Enferm USP. 2011 Abr; 45(2):369-71.

9. Roelf SB, Nieuwenhuis MK, Tuinebreijer WE, Aardenburg B. Effect of training in the emergency management of severe burns on the knowledge and performance of emergency care workers as measured by an online simulated burn incident. Burns. 2011 Mar; 37(2):282-7.

10. Kut A, Ucku V, Pelgur H, Kesik E, Basaran O. Knowledge, attitudes, and behaviors toward burn injuries by nurses, midwifes, and paramedics. Burns. 2007 Feb; 33(1):48.

11. Lam NN, Dungburns NT. First aid and initial management for childhood burns in Vietnam - an appeal for public and continuing medical education. Burns. 2008 Feb; 34(1):67-70. 
12. Pasquali, L. Princípios de elaboração de escalas psicológicas. Rev Psiquiatr Clín. 1998 Set-Out; 25(5):206-13.

13. Lima TC, Gallani MCBJ, Freitas MIP. Validação do conteúdo de instrumento para caracterizar pessoas maiores de 50 anos portadoras do Vírus da Imunodeficiência Humana/Síndrome da Imunodeficiência Adquirida. Acta Paul Enferm. 2012 Mai; 25(1):4-10.

14. Bellucci Júnior JA, Matsuda LM. Construção e validação de instrumento para avaliação do Acolhimento com Classificação de Risco. Rev Bras Enferm. 2012 Set-Out; 65(5):751-7.

15. Polit DF, Beck CT, Hungler BP. Análise quantitativa. In: Polit DF, Beck CT, Hungler BP. Fundamentos de pesquisa em enfermagem: métodos, avaliação e utilização. $5^{\text {a }}$ ed. Porto Alegre (RS): Artmed; 2004. p.167-98.
16. Pasquali, L. Psicometria: teoria dos testes na psicologia e na educação. Petrópolis (RJ): Editora Vozes; 2003.

17. Oliveira MS, Fernandes AFC, Sawada NO. Manual educativo para o autocuidado da mulher mastectomizada: um estudo de validação. Texto Contexto Enferm. 2008 Jan-Mar; 17(1):115-23.

18. Bortolotti SLV, Andrade DF. Aplicação de um Modelo de Desdobramento Graduado Generalizado - GGUM da Teoria da Resposta ao Item. Est Aval Educ. 2007 Mai-Ago; 18(37):157-88.

19. Kuwabara CCT, Évora YDM, Oliveira MMB. Gerenciamento de risco em tecnovigilância: construção e validação de instrumento de avaliação de produto médico-hospitalar. Rev Latino-Am Enferm. 2010 Set-Out [acesso 2013 Jan 25]; 18(5). Disponível em: http://www.scielo. $\mathrm{br} /$ scielo.php?script=sci_arttext\&pid=S0104$11692010000500015 \& \operatorname{lng}=$ en\&nrm=iso 